UDC 633.39:582.663.2:631.5

DOI https://doi.org/10.32851/2226-0099.2021.122.24

\title{
ELEMENTS OF AMARANTH CULTIVATION TECHNOLOGY AND POST-HARVEST PROCESSING OF AMARANTH GRAIN
}

\author{
Valentiuk N.O. - Candidate of Technical Sciences, \\ Assistant at the Department of Field and Vegetable Crops, \\ Odesa State Agrarian University \\ Yurkevych Ye.O. - Doctor of Agricultural Sciences, \\ Professor, at the Department of Field and Vegetable Crops, \\ Odesa State Agrarian University \\ Kohut I.M. - Candidate of Agricultural Sciences, Associate Professor
}

Modern conditions of fierce competition in the food market determine the reorientation of agricultural production to meet the needs not only of the population of Ukraine, but also to take into account world market demand. As a result, the task of including new, more universal models in the range of field crops becomes urgent. Among such non-traditional crops, amaranth should be especially noted. Amaranth is a high-protein plant that is willingly eaten by all species of animals. In terms of protein and other valuable substances, amaranth is not inferior to traditional, the most common crops. In addition to the content of protein balanced in its amino acid composition, amaranth grain is characterized by the presence in the oil of a substance such as squalene, which is a source of oxygen, facilities its movement in the body, and has a high ability to penetrate cells through the skin. The latter makes its application valuable in treating burns, as well as in dermatological practice, dentistry, cosmetology. This leads to an extremely wide range of uses of amaranth in the processing industry. Growing and using amaranth in various directions today is a promising type of production activity. The crop is characterized by high adaptive potential and yield of both green mass and grain. The basis for the formation of high seed yield of amaranth is the creation of optimal conditions for plant growth and development. Among the agricultural practices that are able to regulate these conditions, it is important to choose the optimal sowing time and depth of seed wrapping and determine the optimal feeding area and its configuration. In addition, these measures affect the quality of raw materials. The paper presents the review of cultivation technology elements and the technology of primary processing of freshly harvested amaranth grain, which allows us to maintain its quality indicators at the appropriate level until the next target processing.

Key words: amaranth, amaranth grain, agrotechnology of cultivation, agricultural practices, technology of primary processing.

Валентюк Н.О., Юркевич Е.О., Когут І.М. Елементи технології вирощування амаранту і післязбиральної обробки зерна амаранту

Сучасні умови жорсткої конкуренції на ринку харчових продуктів зумовлюють переорієнтацію аграрного виробництва на задоволення потреб не тільки населення України, але і врахування світового ринкового попиту. Через ие актуальним стає завдання ввести в асортимент польових культур нові, більш універсальні зразки. Серед таких нетрадиційних культур особливо треба відзначити амарант - високобілкову рослину, яку охоче поїдають усі види тварин. За вмістом протеїну та інших иінних речовин амарант не поступається традиційним найпоширенішим культурам. Окрім умісту збалансованого за своїм амінокислотним складом білка, зерно амаранту характеризується наявністю в олії такої речовини, як сквален, який є джерелом забезпечення організму киснем, сприяє його переміщенню в організмі, а також має високу спроможність проникати у клітини організму через шкіру, шо забезпечує високу ефективність його застосування у разі опіків, у дерматологічній практиці, стоматології, косметології. Це зумовлює надзвичайно широкий спектр використання амаранту у переробній галузі. Вирощування $і$ використання амаранту у різних напрямках нині є перспективним видом виробничої діяльності. Культура характеризується високим адаптивним потенціалом і врожайністю як зеленої маси, так $i$ зерна. Основою формування високої насіннєвої врожайності амаранту є створення оптимальних умов для росту і розвитку рослин. Серед агрозаходів, спроможних регулювати ці умови, важливе значення має вибір оптимального строку сівби і гли- 
бини загортання насіння, визначення оптимальної площі живлення та ії конфігуращії. До того ж иі заходи впливають на показники якості сировини. У роботі представлено огляд елементів агрономічної технології вирощування і технології первинної обробки свіжого зібраного зерна амаранту, що дозволяє зберегти його якісні показники на належному рівні до наступної иільової переробки.

Ключові слова: амарант, зерно амаранту, агрономічна технологія вирощування, агрозаходи, технологія первинної обробки.

Formulation of the problem. Recently, there has been a significant acceleration in the pace of life, as a result of which a person is not always able to monitor their diet. This in turn affects her health and therefore her quality of life. Today, producers are trying to provide people requiring special needs with food of a new range within functional products. This encourages producers to find and attract a variety of plant materials that can provide a balanced diet. For some time, the attention of both growers and researchers has been paid to such a plant as amaranth. For Ukraine, amaranth is a non-traditional crop, which is grown in highly limited quantities. But due to its unique properties, this crop is able to take its place along with other oilseeds.

Analysis of recent research and publications. The ancient amaranth crop along with corn and quinoa has been the main grain crop for Native Americans for about 6,000 years. It was of great economic importance to the Inca and Aztec civilizations. This is evidenced by the fact that in the XV century the last Aztec emperor received a tax in amaranth grain. Amaranth grain was so highly valued that it was considered the equivalent of gold. Although amaranth has been known since ancient times, for a long time this culture has not been given importance. Amaranth was mentioned in the early twentieth century, when scientists became concerned about population growth on the planet and began looking for a plant that could balance the range of foods for mankind, as published by Khokhlachov V.V. [1].

The founder of the study of amaranth was a world-famous scientist Vavilov N.I. [2]. He summarized the experience gained by mankind on the introduction of plants, i.e. movement and cultivation of plant flora in different climatic zones and continents, developed the theoretical basis of selection and created the world's first bank of germoplasm (seed samples). At the same time from his scientific works one plant can clearly stands out among the non-traditional in the production - that is an amaranth. He managed to get encouraging results, but with the death of Vavilov N.I., the study of amaranth was largely abandoned.

During 1931 - 1941 Shlykov G.N. [3] studied about 260 samples of 35 species of amaranth in order to find new cereals among them, fodder and silage species. Based on research, it was found that such species of amaranth as A. saudatus and A. ranisulatus have a high level of yield of green mass and grain and can be included in the cultural flora of the USSR. But in the late 1940s, during the Lysenkiv region, research in this direction was stopped, and amaranth was declared an alien plant with which the agents of imperialism wanted to destroy the collective farm fields. Thus, for the second time in the centuries-old history of amaranth, the death penalty was passed.

The situation changed only in the 70s, but time was lost. Today, dozens of institutes around the world are working to study this culture. Every year amaranth is cultivated in more and more areas of all continents.

It is known that the genus Amaranthus L. - amaranth has about 75 species that grow in warm and temperate zones of the globe. Due to the peculiarities of its chemical composition, this culture has a wide range of uses: medicine and pharmacology, food industry, feed production [2-6]. 
The species composition of amaranth in Ukraine is constantly expanding, which is due to the accidental ingestion of seeds of different species due to the expansion of trade and economic ties between different countries. This is especially evident in ports of world importance.

Amaranth belongs to a group of plants with high-intensity C4-type photosynthesis and is characterized by high ecological plasticity, biological productivity, adaptability and low transpiration coefficient. Amaranth uses 2-3 times less water to form a unit of organic matter compared to other crops.

Amaranth is a high-protein plant that is willingly eaten by all species of animals. In terms of protein and other valuable substances, amaranth is not inferior to traditional, the most common crops. Thus, the protein of amaranth green mass contains 3-3.5 times more than in wheat, and the seeds contain an average of $11.7 \mathrm{~g}$ of lysine per $100 \mathrm{~g}$ of protein, which is 6 times more than in wheat and 2 times - than in soy flour. In terms of quality, on a 100-point scale, amaranth grain protein corresponds to 75 points, while wheat protein is 57 points, soy protein is 68 points, and cow's milk protein is 72 points.

The green mass of amaranth contains an average of 2.5-4.5\% protein, 0.5-1.0 fat, 2.5-4.6 ash, more than $12 \%$ nitrogen-free extractives (BER). $100 \mathrm{~kg}$ of green mass contains 16.3-19.7 feed units, 137-192 g of digestible protein per feed unit, compared to 105 according to the zooengineering norm [1-5].

Amaranth is used to feed animals in the form of green mass, grain, haylage, cutting, feed pellets, briquettes, grass flour. The mass with other crops (cereals) is well ensiled.

In addition to all above, the characteristics of amaranth grain include the presence of a substance such a squalene in amaranth oil. According to the results of medical research, squalene acts as a regulator of lipid metabolism in the human body, it has great antioxidant properties.

All this suggests the extraordinary attractiveness of growing amaranth for growers.

The technological process of post-harvest processing of grain involves the following operations: cleaning, drying (active ventilation), temporary storage of grain [7-9].

The organization and conduct of the process of post-harvest processing of grain is based on in-depth study and analysis of such properties of grain mass and its components as physical and technological (moisture content, flowability, natural (volume) mass, weight of 1000 grains), hygroscopic (equilibrium humidity), aerodynamic (aerodynamic drag of the grain layer, soaring speed, windage coefficient), thermophysical (thermal conductivity, thermal diffusivity, heat and moisture transfer), biochemical and microbiological $[7,8,10]$.

When cleaning grain from impurities, differences in the following physical and mechanical properties of grain and impurities are used: geometric dimensions (length, width and thickness) of impurities and the main crop; density; aerodynamic properties (speed of soaring) of grain and impurities; shape (round, oblong) and surface condition (smooth, rough) of grains and impurities; magnetic properties of metal-magnetic impurities; color, as published by Voblikov Ye.B. [7].

The sequence and number of operations for removal impurities from grain depends not only on the condition of the raw material, namely its clogging and moisture, but also its immediate purpose $[7 ; 10]$.

Natural and climatic conditions of Ukraine and physiological features of this culture determine a fairly high $(20 \ldots 25 \%)$ humidity of amaranth grain during harvest. For reliable storage, amaranth grain must be dried to the conditional humidity as soon as possible. 
In the technology of post-harvest processing of grain, the drying process is the most energy-intensive [8; 10].

Of all currently available methods of grain drying (thermal, special and mechanical), the most common is the thermal method using convective drying [8; 9].

The peculiarities of drying small grain crops, in particular amaranth, are that they have a high bulk density, which depends little on the method of laying (gravitational or inertial), and is due to their botanical properties, expressed in shape, linear size and size. The consequence of this is a small amount of intergranular spaces in the grain layer of small-seeded (amaranth), and the corresponding high value of the aerodynamic drag of such a layer. This indicator leads to a low speed of the drying agent and its uneven distribution in a dense stationary or gravitational state of the grain during drying, which in turn leads to low heat and mass transfer coefficients, as well as uneven heating of the grain mass. These features complicate the selection of operating modes of the respective drying units.

Formulating the goals. Although, the technology of growing amaranth for grain has been developed and recommended for production within previous years, we can see that it requires significant improvement and additional further study along with the reconsideration of basic provisions in current conditions. There can be no universal technology for crop cultivation and which is also applicable to amaranth. Farmers need to adapt a variety of technologies already known for its cultivation to specific growing conditions, which are determined by a set of indicators. In modern conditions, this factor acquires special significance for dramatic climate change towards an increase of air temperature, reducing moisture provision and the novelties in agricultural production. This is becoming certainly relevant for the zone of risky agriculture in the southern region of Ukraine. We have to reconsider some approaches to establishing optimal standards concerning weight norms of amaranth sowing, formation of sowing density due to change of row spacing, distance between plants in a row for the newest high-yielding varieties of amaranth. Climate change also imposes certain requirements on the care system for amaranth crops. With the deterioration and increasing aggressiveness of the phytosanitary condition of amaranth crops the technology of its cultivation and measures to protect crops from pests acquires significant relevance throughout the terms of vegetation and before its harvesting.

The harvested amaranth grain, like any other crop, must be preserved with minimal losses in its quality. During the harvest period, amaranth may have high grain moisture, which in the absence of appropriate measures can lead to crop loss. To prevent this, a set of post-harvest grain processing operations has been designed, which involves cleaning, drying and storage.

Presentation of the main research material. One of the main indicators of the process of growing crops is their yield, the value of which largely depends on many environmental factors that develop during the growing season.

Agrotechniques are the parameters of field ecological system management. Only with a high severity of the reaction of the agrocenosis to the control parameters we can achieve high efficiency of the control system, i.e. technology.

Based on this, the maximum reactivity of the genetic system of plants to the west should be considered as the susceptibility of the system to control its production process. The density of the agrocenosis significantly affects the realization of the production potential of the agrocenosis, its structural organization.

This means that agronomic measures should be aimed at maximizing the needs of the plant and adaptation to the environment to identify the maximum opportunities of 
the species (variety) along with the interaction of plants with each other, with the environment, efficient use of solar energy by crops and region of plant alimentation. The maximum balance of these factors can increase seed yield and quality.

There are different points of view on how to sow amaranth. So Behatsky Yu.S. and others (1995) believed that the optimal method is sowing with a row spacing of $45 \mathrm{~cm}$, which provides the highest level of seed productivity compared to the continuous method. Shevchenko E.N. (1997) considers that the width of a row spacing of $45 \mathrm{~cm}$ at a density of standing of plants of 0,5 million pieces / hectare is optimum both at cultivation of amaranth on green plant mass, and on grain. In terms of irrigation in the Central Forest-Steppe, according to Shelest V.K. et al (1995), the largest collection of green mass of amaranth paniculata is provided at a seeding rate of $1 \mathrm{~kg} /$ ha of similar seeds and a row spacing of $45 \mathrm{~cm}$. Goptsiy T.I. [12] found that when growing amaranth paniculata on the green mass can be considered the best row spacing of $15 \mathrm{~cm}$ and plant density of 1330 thousand / ha and 670 thousand / ha.

In studies conducted by Dudka M.I. [13] showed that the highest grain yield of amaranth hairy $(1.77 \mathrm{t} / \mathrm{ha})$ was obtained by a wide-row $(45 \mathrm{~cm})$ method of sowing with a seeding rate of $1.0 \mathrm{~kg} / \mathrm{ha}$. In this case, the author noted that the use of complete mineral fertilizer $\left(\mathrm{N}_{60-90} \mathrm{P}_{60-90} \mathrm{~K}_{30}\right)$ provides an increase in grain yield by $0.39-0.42 \mathrm{t} / \mathrm{ha}$.

Thus, sowing amaranth with a row spacing of $45 \mathrm{~cm}$ allows to obtain the best results of grain yield $[13 ; 14]$.

The limited reviews of known studies undertaken on certain issues of amaranth cultivation technology appeared hereabove in the article, does not provide the complete insight of how efficient are the existing recommendations for its cultivation in various soil types and climatic conditions.

Successful cultivation of amaranth and obtaining the greatest economic efficiency in the face of severe challenges of nature over the past five years has become only possible with introducing the basic adaptation of existing technologies for cultivating this crop, both grain and green fodder based on specific environmental factors and technical and economic farmers' facilities.

The quality of the products which get when growing field crops plays no less important role than the level of yield.

Commercial qualities of amaranth seeds are determined by the biological characteristics of the variety, soil and climatic conditions, as well as agricultural cultivation measures. One of the main indicators that determines the quality of amaranth seeds is the content of crude fat or oil. Amaranth oil is unique in its properties, because, along with other important components for humans, it contains about $8 \%$ squalene, which is a powerful immunostimulant.

Another value of amaranth seeds is vegetable protein, which leaves far behind clover, buckwheat and soy, and among animal proteins - even cow's milk.

After harvesting in terms for reliable storage of amaranth grain mass before further processing, it must meet the following requirements: grain moisture not more than $9 \%$, clogging - not more than $2 \%$. Therefore, to prevent losses, it is necessary to timely clean and dry the grain, as high humidity and clogging will promote the development of microflora, increase the intensity of grain respiration, and can lead to such a negative phenomenon as self-heating of grain mass and, consequently, its loss.

As amaranth cultivation has not yet become mass-produced, and small farms are not always able to deliver small batches to industrial grain mills and elevators in time, it is advisable to build a mini-elevator for post-harvest processing and storage of amaranth grain, which can be used and for other small-seeded crops. 
The following technological operations are planned to be carried out at the mini-elevator: acceptance from motor transport, supply of grain for cleaning, supply of raw or wet grain for drying, storage and release for motor transport.

Schematic diagram of a mini-elevator for post-harvest processing and storage of amaranth grain is shown in fig. 1 .

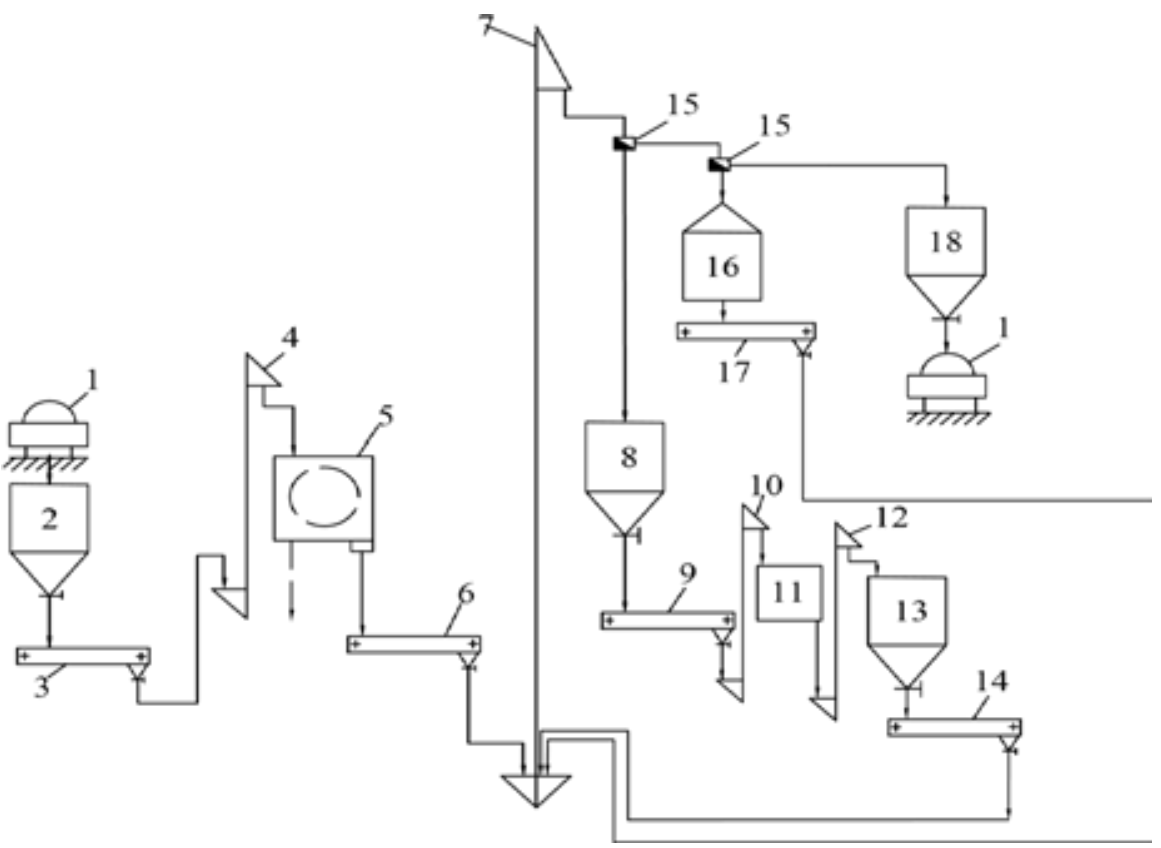

Fig. 1. Schematic diagram of a mini-elevator for post-harvest processing and storage of amaranth

Inlet, cleaning, drying and storage: the grain from the truck 1 enters the receiving hopper 2, from which the conveyor 3 and the noria 4 . Next, the product is pre-cleaned on the separator 5 and fed to the conveyor 6 , which in turn feeds the grain to the noria 7 . Next, through the check valves 15 , the dry grain is fed to the silos 16 , and the wet enters the drying hopper 8, from which the conveyor 9 and the specialized batch 10 , which feeds the product into the dryer 11 . Then the already dried grain is removed from the dryer noria 12 and fed into the post-drying hopper, and then to the conveyor 14 and the noria 2.

Outlet: the product from the silos 16, enters the silage conveyors 17 , respectively, which supply grain to the noria 2 . From the noria through the check valves 15 the product enters the release storage hopper 18, and from it to the car body 1 .

Smirnov S. proposed a line for preparing grain for grinding: the grain from the hopper goes to a vibrating separator, which separates large, light and small impurities. After separation of impurities other than grain in width (for amaranth), processing is performed on a pneumatic aspirator to remove aero-separating impurities. Then it follows by carrying out intensive cleaning of the grain surface and removal of lumps of earth, shells, damaged grains on a grain-cleaning machine with simultaneous passage through a pneumatic aspirator to separate the shells. After cleaning, the grain is moistened on a 
humidifying machine and moistened for 6 hours, then weighed and sent to the shredded system 1 [15].

Installation and use of such a line is advisable directly at processing plants, and for small farms it will be more appropriate to build a mini-elevator as shown in Fig. 1 scheme, as the scheme allows one to prepare amaranth grain not only for processing into flour, but also for other purposes, as well as for temporary storage. The organization and maintenance of the technological process of post-harvest processing of amaranth grain done according to the above scheme will ensure the preservation of quality indicators of amaranth grain until further processing.

Conclusions and suggestions. Reconsideration of the following conceptual approach to the development of new and improvement of already existing technologies of amaranth cultivation will enable the creation of preconditions for achieving stable, bioclimatic potential, energy and economically justified yields of amaranth under conditions of expanded restoration of soil fertility and environmental safety as well as cultivated products.

To ensure reliable storage of amaranth grain without loss of quality, it is necessary to ensure timely post-harvest processing of grain. The organization of post-harvest processing according to the basic scheme, which provides for cleaning, drying, temporary storage and release of grain, is able to maintain the quality of amaranth grain at the appropriate level.

\section{REFERENCES:}

1. Хохлачов В.В. Хліб на день прийдешній: секрет амаранту. Вісник АН України. 1992. № 2. С. 16-22.

2. Вавилов Н.И. Происхождение и география культурных растений. Ленинград : Наука. 1987. 386 с.

3. Шлыков Г.Н. Интродукция и акклиматизация растений. Москва : Изд. с.-х. литературы журналов и плакатов. 1963. 487c.

4. Sounders P.M., Becker R. Amaranthus: A potential food and feed resource. Advances in cereal science and technology. 1984. Vol. 6. P. 357-386.

5. Tucker. J.B. Amaranth: the once and future crop. Bioscience. 1986. № 36. P. 59-60.

6. Weber L., Kaufman C. Plant breeding and seed production. University Minnesota: St. Paul, 1990. P. 34-40.

7. Вобликов Е.Б., Буханцов В.А., Маратов Б.К. и др. Послеуборочная обработка и хранение зерна. Ростов н/Д: издательский центр «МарТ», 2001. 240 с.

8. Малин Н.И. Энергосберегающая сушка зерна. Москва : Колос, 2004. 240 с.

9. Станкевич Г. М., Страхова Т.В, Атаназевич B.I. Сушіння зерна: підруч. Київ : Либідь, 1997. 351 с.

10. Атаназевич В.И. Сушка зерна. Москва : Лабиринт, 1997. 255 с.

11. Высочина Г.И. Амарант (amaranthus 1): химический состав и перспективы использования (обзор). Химия растительного сырья. 2013. № 2. С. 5-14.

12. Гопцій T.I. Амарант: біологія, вирощування, перспективи використання, селекція. Харків, 1999. 273 с.

13. Дудка М. І. Вплив способу сівби, норми висіву і рівня мінерального живлення на продуктивність амаранту волотистого. Рослинництвво та трунтознавство. 2020. Вип. 11, № 1. С. 23-32.

14. Гусєв М.Г., Войташенко Д. П. Продуктивність амаранту зернового напрямку залежно від способу сівби та норми висіву. Зрошуване землеробство. Херсон: Айлант, 2006. Вип. 46. С. 109-112.

15. Смирнов С. Технология очистки зерна амаранта перед помолом. Хлебопродукты. 2006. № 2. С. 50-52. 